\title{
N Sources and Doses on Japonese Cucumber Yield and Nitrate Accumulation in Fruits in Greenhouse
}

\author{
Mônica Lima Alves Pôrto ${ }^{1}$, Mario Puiati ${ }^{2}$, Paulo Cezar Rezende Fontes ${ }^{2}$, Paulo Roberto Cecon ${ }^{3}$ \\ $\&$ Jailson do Carmo Alves ${ }^{1}$ \\ ${ }^{1}$ Instituto Federal de Alagoas, Campus Maragogi, Maragogi, Alagoas, Brazil \\ ${ }^{2}$ Departamento de Fitotecnia, Universidade Federal de Viçosa, Viçosa, Minas Gerais, Brazil \\ ${ }^{2}$ Departamento de Estatística, Universidade Federal de Viçosa, Viçosa, Minas Gerais, Brazil \\ Correspondence: Mônica Lima Alves Pôrto, Instituto Federal de Alagoas, Campus Maragogi, Rodovia AL 101 \\ Norte, Km 139, Peroba, Maragogi, Alagoas, 57.955-000, Brazil. Tel: 55-82-999-502-430. E-mail: \\ monicalporto@yahoo.com.br
}

$\begin{array}{lcc}\text { Received: June 7, 2018 } & \text { Accepted: July 19, } 2018 & \text { Online Published: September 15, } 2018 \\ \text { doi:10.5539/jas.v10n10p468 } & \text { URL: https://doi.org/10.5539/jas.v10n10p468 }\end{array}$

\begin{abstract}
Despite Japanese cucumber nutritional and commercial importance, few studies have been carried out with the nitrogen $(\mathrm{N})$ fertilization of the crop, especially in greenhouse conditions. This study objective was to evaluate the Japanese cucumber yield and nitrate $\left(\mathrm{NO}_{3}{ }^{-}\right)$accumulation in the fruits in greenhouse as a function of the $\mathrm{N}$ sources and doses at Viçosa, Minas Gerais State, Brazil. The experiment was set in a randomized complete block design, arranged in a $2 \times 5$ factorial scheme, with two $\mathrm{N}$ sources (ammonium sulphate and ammonium nitrate) and five $\mathrm{N}$ doses $\left(0 ; 75 ; 150 ; 300\right.$ and $\left.600 \mathrm{~kg} \mathrm{ha}^{-1}\right)$, with four replicates. The number of fruits per plant, average fruit mass, fruits yield and $\mathrm{NO}_{3}{ }^{-}$accumulation in the fruits were evaluated. The maximum economic efficiency $\mathrm{N}$ doses for two $\mathrm{N}$ sources used was calculated according to the prices of the fertilizers and Japanese cucumber fruits practiced in 2010. There were no significant effects of $\mathrm{N}$ sources and of the interaction between $\mathrm{N}$ sources and $\mathrm{N}$ doses for the productive characteristics (number of fruits per plant, average fruit mass and fruits yield) of the Japanese cucumber. However, all the productive characteristics of the Japanese cucumber increased following a quadratic model as a function of the $\mathrm{N}$ doses. The maximum economic efficiency $\mathrm{N}$ doses for the fruits yield of Japanese cucumber were $398 \mathrm{~kg} \mathrm{ha}^{-1}$ and $386 \mathrm{~kg} \mathrm{ha}^{-1}$, resulting in fruits yield of $76.38 \mathrm{t} \mathrm{ha}^{-1}$ and $76.29 \mathrm{t} \mathrm{ha}^{-1}$, for the ammonium sulphate and ammonium nitrate, respectively. $\mathrm{NO}_{3}{ }^{-}$accumulation in Japanese cucumber fruits as a function of the $\mathrm{N}$ doses for two $\mathrm{N}$ sources evaluated was not verified.
\end{abstract}

Keywords: Cucumis sativus, economical efficiency, nitrogen, production

\section{Introduction}

In Brazil, cucumber (Cucumis sativus L.) is intensively cultivated in greenhouse, especially the Japanese type cultivars. The use of this cultivation system has resulted in great benefits, especially for small and medium farmers, such as increased of fruits yield and quality, reduction of seasonality of production and a significant increase in profitability (Santi et al., 2013; Pôrto et al., 2014a).

Currently, there is a growing demand for information on the use of correctives and fertilizers for vegetables grown in greenhouse, especially concerning the definition of doses and forms of application of these materials. Information concerning the nutrient uptake and fertilization of Japanese cucumber grown in greenhouse is very scarce in the literature. It should be considered that the loss of nutrients by leaching and/or volatilization is lower than in open field cultivation and that the cultivars used are more productive, responding to higher amounts of nutrients (Blanco, 2006).

Nitrogen $(\mathrm{N})$ is one of the nutrients most required and uptaken by plants, being the $\mathrm{N}$ fertilization of great importance to vegetables yield (Filgueira, 2008). $\mathrm{N}$ is a nutrient that influences the processes involved in plant growth and development, altering the source/drain relationship and, consequently, the distribution of assimilates between vegetative and reproductive organs. In cucurbits, the increase of the $\mathrm{N}$ dose, up to a certain limit, results in increase in the leaf area of the plant; therefore, exerts influence on the production of photoassimilates and, consequently, on fruits yield (Queiroga et al., 2007). 
The appropriate $\mathrm{N}$ dose is variable according to several factors, including the expected yield, cultivar, management practices and soil and climate conditions (Pôrto et al., 2012b). Another aspect that should be considered in the management of $\mathrm{N}$ fertilization to crops is related to $\mathrm{N}$ source used, because it influences the uptake and metabolism of $\mathrm{N}$ by plants, there is a need to determine the best $\mathrm{N}$ source as a function of the plant species and the quality of the product to be used in the human consumption (Silva et al., 2017). The N source used plays an important role in regulating $\mathrm{N}$ transformations, changing $\mathrm{N}$ loss patterns and influencing $\mathrm{N}$ use efficiency by plants (Abbasi et al., 2013). In general, the $\mathrm{N}$ fertilizer sources have one of the following $\mathrm{N}$ forms: amide $\left(\mathrm{CO}\left(\mathrm{NH}_{2}\right)_{2}\right)$, ammonium $\left(\mathrm{NH}_{4}{ }^{+}\right)$and nitrate $\left(\mathrm{NO}_{3}{ }^{-}\right)$, being the $\mathrm{N}$-amide and $\mathrm{N}$-ammoniacal sources the most used in agricultural crops in the world (Silva et al., 2017). $\mathrm{NO}_{3}{ }^{-}$is the main form of $\mathrm{N}$ uptaken by plants, but they can also uptake this nutrient in the form of $\mathrm{NH}_{4}{ }^{+}$or both. The most crops grow best with a mixture of $\mathrm{NO}_{3}{ }^{-}$and $\mathrm{NH}_{4}{ }^{+}$sources, although many studies present inconsistent responses (Abbasi et al., 2013; Silva et al., 2017). Currently, information on the use of $\mathrm{N}$ sources and the definition of adequate $\mathrm{N}$ dose for the Japanese cucumber cultivated in greenhouses are very scarce in the literature for the Brazilian conditions, being this definition of extreme importance to contribute to a better exploitation of the productive potential of the crop in this cultivation system.

Despite the importance of $\mathrm{N}$ fertilization for the vegetables yield, this practice is currently a controversial issue, because when applied in excess can result in the reduction of nutritional quality and security due to the $\mathrm{NO}_{3}{ }^{-}$ accumulation (Pôrto et al., 2012b, 2014b). $\mathrm{NO}_{3}{ }^{-}$when ingested in large amounts by humans can cause serious health consequences, such as formation of nitrosamines, a potentially carcinogenic substance, as well as methemoglobinemia or blue blood that reduces the oxygen transportation in the blood (Santamaria, 2006; Pôrto et al., 2012a; Silva et al., 2017).

Some studies show that vegetables correspond to the food group that contributes most to the intake of $\mathrm{NO}_{3}{ }^{-}$by humans, being responsible for about 72 and $94 \%$ of the daily intake (Pôrto et al., 2012b). In general, leafy vegetables such as lettuce, spinach, cabbage, arugula, among others, have tendency to accumulate high $\mathrm{NO}_{3}{ }^{-}$ concentration in their leaves (Pôrto et al., 2008; Ohse et al., 2012), existing a great interest in monitoring the $\mathrm{NO}_{3}{ }^{-}$concentration in these plants. Flower and fruit vegetables, such as cauliflower, tomato, squash, zucchini, usually show less tendency to $\mathrm{NO}_{3}{ }^{-}$accumulation (Santamaria, 2006; Pôrto et al., 2014b, Silva et al., 2017). Concerning Japanese cucumber crop, information on the $\mathrm{NO}_{3}{ }^{-}$accumulation in the fruits, as well the influence of $\mathrm{N}$ sources and doses on this accumulation, is very scarce in the literature, especially in greenhouse conditions.

This study objective was to evaluate the Japanese cucumber yield and $\mathrm{NO}_{3}^{-}$accumulation in the fruits in greenhouse as a function of $\mathrm{N}$ sources and doses.

\section{Method}

\subsection{Location and Experimental Area}

The experiment was carried out at the horticulture experimental field of the Departmento de Fitotecnia (DFT) at Universidade Federal de Viçosa (UFV), in Viçosa, Minas Gerais State, Brazil, from September to December 2010.

The municipality of Viçosa presents the following geographic coordinates $20^{\circ} 45^{\prime} \mathrm{S}$ and $42^{\circ} 51^{\prime} \mathrm{W}$, and approximately $651 \mathrm{~m}$ of altitude. The climate of the region, according to the Köppen-Geiger classification, is the Cwa (humid subtropical climate), with wet summers and dry winters, with an average annual precipitation of $1,340 \mathrm{~mm}$ and average relative humidity of $80 \%$. The average maximum and minimum temperatures are $22.1{ }^{\circ} \mathrm{C}$ and $15.0^{\circ} \mathrm{C}$ (Santos et al., 2011).

The soil used in Japabese cucumber cultivation was classified as Cambic Red-Yellow Argisol (EMBRAPA, 2013), collected in native forest remnant area. The chemical characteristics and granulometric analysis were determined according to the methods described in EMBRAPA (1997), and the following results were obtained: $\mathrm{pH}\left(\mathrm{H}_{2} \mathrm{O}\right): 5.5 ; \mathrm{P}: 2.6 \mathrm{mg} \mathrm{dm}{ }^{-3} ; \mathrm{K}^{+}: 24.0 \mathrm{mg} \mathrm{dm}{ }^{-3} ; \mathrm{Ca}^{2+}: 0.2 \mathrm{cmol}_{\mathrm{c}} \mathrm{dm}^{-3} ; \mathrm{Mg}^{2+}: 0.1 \mathrm{cmol}_{\mathrm{c}} \mathrm{dm}^{-3} ; \mathrm{S}^{-S^{2}}{ }_{4}^{2-}: 49.4 \mathrm{mg}$ $\mathrm{dm}^{-3} ; \mathrm{Al}^{3+}: 0.4 \mathrm{cmol}_{\mathrm{c}} \mathrm{dm}^{-3} ; \mathrm{H}+\mathrm{Al}: 3.80 \mathrm{cmol}_{\mathrm{c}} \mathrm{dm}^{-3}$; organic matter: $0.7 \mathrm{~g} \mathrm{~kg}^{-1}$; and very clay texture.

\subsection{Treatments and Experimental Design}

The experiment was set in a randomized complete block design, arranged in a $2 \times 5$ factorial scheme, with two $\mathrm{N}$ sources (ammonium sulphate and ammonium nitrate) and five $\mathrm{N}$ doses $\left(0 ; 75 ; 150 ; 300\right.$ and $\left.600 \mathrm{~kg} \mathrm{ha}^{-1}\right)$, with four replicates. 


\subsection{Plant Material and Experimental Procedures}

The 'Taisho' hybrid (ginoic and parthenocarpic) of Japanese cucumber was grown in a chapel type greenhouse, (dimensions: width of $10 \mathrm{~m}$, length of $12 \mathrm{~m}$ and ridge height $2.5 \mathrm{~m}$ ), with retractable side curtains, and covered with $150 \mu \mathrm{m}$ crystal clear polyethylene film treated for ultraviolet radiation, in masonry seedbeds filled with soil.

During the experimental period, the average values of the maximum and minimum temperature and relative humidity inside of the greenhouse were: $33.1{ }^{\circ} \mathrm{C}, 17.1{ }^{\circ} \mathrm{C}$ and $65.5 \%$, respectively, values within the range suitable for cucumber cultivation (Fontes \& Puiatti, 2005).

The seedlings were produced in expanded polystyrene trays with 128 cells. A commercial substrate (Plantmax $\left.{ }^{\circledR}\right)$ was used for sowing, with two seeds being placed in each cell. Seedlings were thinned 3 days after emergence, leaving only one plant per cell. The sowing was performed on 09/03/2010 and the seedlings transplanted to the place of cultivation on 09/21/2010, when they presented two definitive leaves.

Liming and fertilization with $\mathrm{P}, \mathrm{K}$ and micronutrients was carried out based on the soil analysis, according to the recommendations suggested for cucumber cultivation in the Minas Gerais State, Brazil (Ribeiro et al., 1999). The liming consisted of the application of $4.8 \mathrm{t} \mathrm{ha}^{-1}$ of dolomitic limestone, performed 60 days before seedlings transplanting. Fertilization consisted of the application of $1,500 \mathrm{~kg} \mathrm{ha}^{-1}$ of single superphosphate, $200 \mathrm{~kg} \mathrm{ha}^{-1} \mathrm{of}$ potassium chloride, $15 \mathrm{~kg} \mathrm{ha}^{-1}$ of zinc sulphate, $10 \mathrm{~kg} \mathrm{ha}^{-1}$ of borax, $10 \mathrm{~kg} \mathrm{ha}^{-1}$ of copper sulphate and $0.5 \mathrm{~kg} \mathrm{ha}^{-1}$ of ammonium molybdate. $\mathrm{N}$ fertilization was performed according to the studied treatments. Base fertilization ( $100 \%$ of micronutrients and $\mathrm{P}, 30 \%$ of $\mathrm{N}$ and $40 \%$ of $\mathrm{K}$ ) were applied at 10 days before seedlings transplanting. Coverage fertilizations ( $70 \%$ of $\mathrm{N}$ and $60 \%$ of $\mathrm{K}$ ) were applied in two equal splits at 15 days and 40 days after seedlings transplantation (Fontes \& Puiatti, 2005).

The Japanese cucumber was grown at $1.0 \times 0.30 \mathrm{~m}$ spacing. The experimental plot consisted of 12 plants, arranged in 2 rows with 6 plants. The working area of the plot consisted of 8 plants ( 4 central plants in each row). The plants were vertically string tutured and maintained with a single stem. It was performed thinning of the lateral branches during cultivation and the apical meristem of the plants was removed when they reached $1.8 \mathrm{~m}$ height. During the experiment drip irrigation was performed to maintain soil moisture near field capacity. Phytosanitary control of pest and disease was carried out through the application of registered pesticides for cucumber cultivation, following the guidelines of the products regarding recommended dosages and application intervals.

\subsection{Harvest and Evaluated Characteristics}

The harvest was carried out from November 4 to December 4, 2010. Harvest period was reduced by the high incidence of Leandria momordicae in the Japanese cucumber plants during the experiment, especially during the period of fruit production. Although frequent applications with pesticides for the control of this disease were carried out, they showed low control efficiency, and this disease contributed to the reduction of the cultural cycle of Japanese cucumber (anticipation of plants senescence).

Fruits were harvested daily at the immature stage when presented commercial characteristics. The number of fruit per plant was obtained by counting all the harvested fruits divided by the number of plants in each treatment. The average fruit mass corresponded to the total fruits production divided by the number of fruits harvested in each treatment. It was also determined the total fruits production per plot in each treatment, being estimated the fruits yield of Japanese cucumber $\left(\mathrm{kg} \mathrm{ha}^{-1}\right)$.

The maximum economic efficiency $\mathrm{N}$ doses were calculated according to the method described by Raij (2011). Equating the first derivate of the regression equation for fruits yield of Japanese cucumber $(\mathrm{a} 1+2 \mathrm{a} 2 \mathrm{x})$ to the equivalence relationship "price of $\mathrm{kg}$ of $\mathrm{N}(\mathrm{c}) / \mathrm{price}$ of $\mathrm{kg}$ of fruits (v)", the relation obtained $[\mathrm{x}$ " $=\mathrm{a} 1-(\mathrm{c} / \mathrm{v}) /$ $2(-\mathrm{a} 2)]$ was used to calculate the maximum economic efficiency $\mathrm{N}$ dose. To determine the maximum economic efficiency $\mathrm{N}$ doses for two $\mathrm{N}$ sources used were considered the prices practiced in Minas Gerais State in 2010, that were $\mathrm{R} \$ 3.00 / \mathrm{kg} \mathrm{N}$ and $\mathrm{R} \$ 7.80 / \mathrm{kg} \mathrm{N}$ for the ammonium sulfate and ammonium nitrate, respectively (CONAB, 2011) and $\mathrm{R} \$ 0.75 / \mathrm{kg}$ of cucumber fruits (CEASA-MG, 2011), resulting in equivalence relationship (c/v) equals 4.0 and 10.4 for ammonium sulfate and ammonium nitrate, respectively.

The nitrate $\left(\mathrm{NO}_{3}{ }^{-}\right)$concentrations on Japanese cucumber fruits were determined using the salicylic acid method (Cataldo et al., 1975). Samples of fruits harvested at the productive peak were used. The fruits were collected, washed with tap water and deionized water, cut into in cubes and dried in a forced-air oven $\left(75^{\circ} \mathrm{C}\right)$ until constant weight. Subsequently, dried fruit samples were ground in a Wiley type mill and sieved in a 20 -mesh screen. After extraction with water in a water bath at $45{ }^{\circ} \mathrm{C}$ for one hour, the $\mathrm{NO}_{3}^{-}$concentrations were determined by colorimetry in a spectrophotometer at $410 \mathrm{~nm}$. 


\subsection{Statistical Analysis}

Data were submitted to the analysis of variance, splitting the quantitative effects of $\mathrm{N}$ doses into regressions, adjusting the equations to adequately express the behavior of the variables. All the analyses were performed using the program SAEG, version 9.1 (SAEG, 2007).

\section{Results and Discussion}

\subsection{Productive Characteristics and Maximum Economic Efficiency $N$ Doses}

There were no significant effects of $\mathrm{N}$ sources and of the interaction between $\mathrm{N}$ sources and $\mathrm{N}$ doses for the productive characteristics (number of fruits per plant, average fruit mass, fruits yield) of the Japanese cucumber. These results demonstrate that both $\mathrm{N}$ sources used (ammonium sulfate and ammonium nitrate) have similar agronomic efficiency for the Japanese cucumber cultivation. The high cost of ammonium nitrate (higher cost per $\mathrm{kg} \mathrm{N}$ ) and the difficulty of acquiring this product in the Brazilian market makes it impracticable its utilization as a $\mathrm{N}$ source, being ammonium sulphate more indicated to Japanese cucumber cultivation in greenhouse because it presents better cost-benefit.

These results corroborate those observed by Silva et al. (2017) which also did not observe differences in the use of different $\mathrm{N}$ sources (ammonium sulfate (100\% ammonium), ammonium nitrate (50\% ammonium and 50\% nitrate), sodium nitrate $(100 \%$ nitrate) and urea $(100 \%$ amide) $)$ on productive characteristics of cucumber (fruit production commercial and non-commercial, fruit mass and number per plant, fruit length, fruit diameter and fruit fresh matter).

$\mathrm{N}$ doses promoted significant effects $(\mathrm{p}<0.01)$ in all the productive characteristics evaluated, demonstrating that the Japanese cucumber is very responsive to increasing of $\mathrm{N}$ supply independent of $\mathrm{N}$ source used. The number of fruits per plant, average fruit mass and fruits yield of Japanese cucumber increased following a quadratic model as a function of the $\mathrm{N}$ doses (Figures 1,2 and 3).

The maximum number of fruits per plant was 20.4 units, obtained with the estimated $\mathrm{N}$ dose of $457 \mathrm{~kg} \mathrm{ha}^{-1}$ (Figure 1); this result corresponds to an increase of $79 \%$ in relation to the lowest $\mathrm{N}$ dose used.

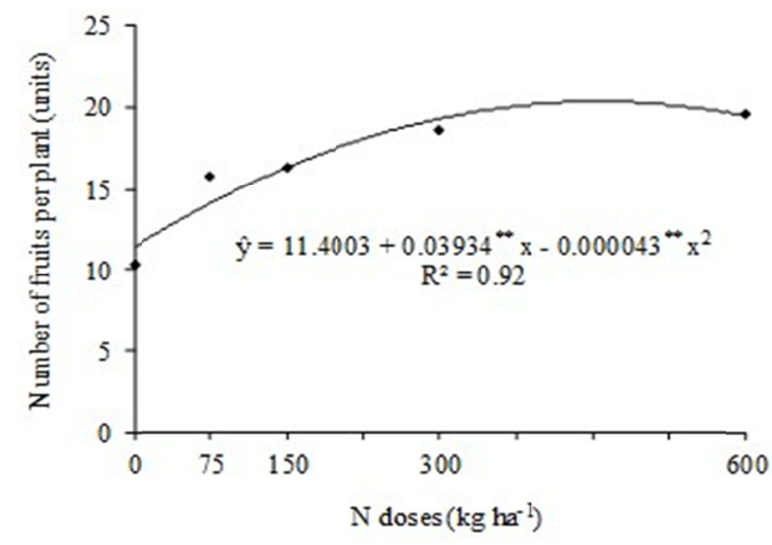

Figure 1. Number of fruits per plant of Japanese cucumber as a function of the $\mathrm{N}$ doses

Note. ${ }^{* *}$ Significant at $\mathrm{p}<0.01$, by $\mathrm{t}$ test.

The estimated $\mathrm{N}$ dose of $357 \mathrm{~kg} \mathrm{ha}^{-1}$ was responsible for the maximum average fruit mass (118.5 $\mathrm{g}$ per fruit) (Figure 2). This result corresponds to an increase of $40 \%$ in relation to the lowest $\mathrm{N}$ dose used. 


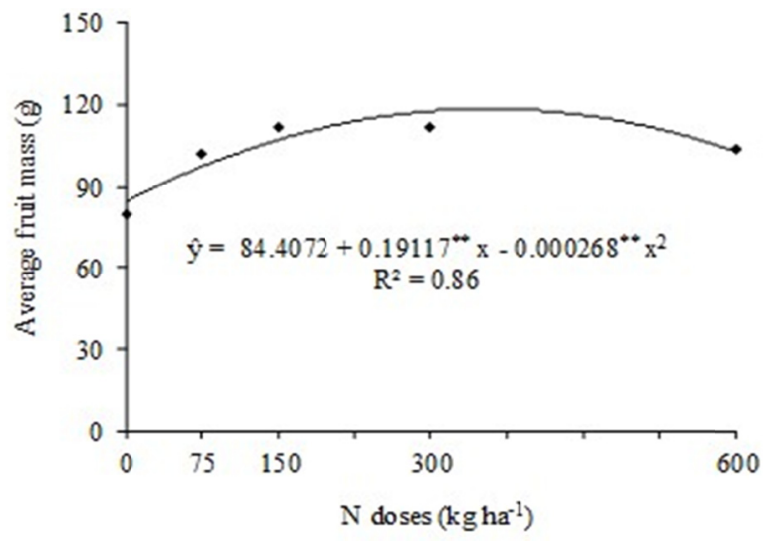

Figure 2. Average fruit mass of Japanese cucumber as a function of the $\mathrm{N}$ doses

Note. ${ }^{* *}$ Significant at $\mathrm{p}<0.01$, by $\mathrm{t}$ test.

The maximum fruits yield $\left(76.4 \mathrm{tha}^{-1}\right)$ of Japanese cucumber was obtained with the estimated $\mathrm{N}$ dose of $406 \mathrm{~kg}$ $\mathrm{ha}^{-1}$ (Figure 3). This result represents an increase of $135 \%$ in relation to the lowest $\mathrm{N}$ dose used.

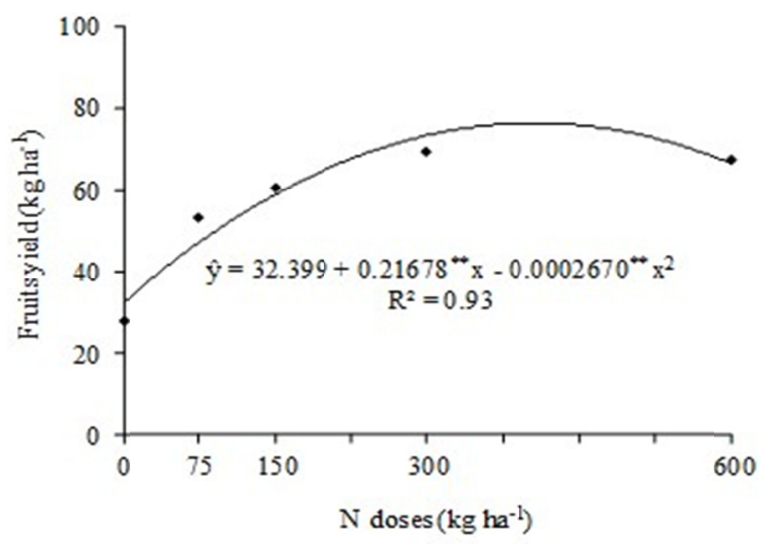

Figure 3. Fruits yield of Japanese cucumber as a function of the $\mathrm{N}$ doses

Note. ${ }^{* *}$ Significant at $\mathrm{p}<0.01$, by $\mathrm{t}$ test.

$\mathrm{N}$ is a nutrient that influences the processes involved in plant growth and development, altering the source/drain relationship and, consequently, the distribution of assimilates between vegetative and reproductive organs. In cucurbits, the increase of the $\mathrm{N}$ dose, up to a certain limit, results in increase in the leaf area of the plant; therefore, exerts influence on the production of photoassimilates and, consequently, on fruits yield (Queiroga et al., 2007).

The results indicate that the effect of $\mathrm{N}$ fertilization on fruits yield of Japanese cucumber is a result of the increase in fruits number and mass. In cucurbits, the response to $\mathrm{N}$ fertilization has been very variable, depending on the species, cultivars and cultivation systems. In other cucurbits such as melon (Queiroga et al., 2007), watermelon (Silva et al., 2015), gherkin (Oliveira et al., 2008), zucchini (Pôrto et al., 2012b), pumpkin (Pôrto et al., 2014b) and african cucumber (Antunes et al., 2014) has also been observed an increase in the number and the average fruit mass and, consequently, of the fruits yield, with the increase of the $\mathrm{N}$ doses.

The maximum fruits yield obtained in this study exceeds the expected yield for the cucumber cultivation in greenhouse with the use of the recommended fertilization for the Minas Gerais state, which is $60 \mathrm{tha}^{-1}$ (Ribeiro et al., 1999). The maximum fruits yield obtained in this study is within the range verified by Cardoso and Silva (2003) for different Japanese cucumber hybrids (Hokuho, Hokushin, Hyuma, KH-705, Natsusuzumi, Nikkey, Rensei, Summer Green, Top Green, Tsuyataro, Yoshinari, BU-92, AF-1327, AF-1328 and AF-1329) cultivated in greenhouse in São Manuel, São Paulo state, Brazil, at two growing seasons (summer crop and autumn-winter crop), which ranged from 48.02 to $111.76 \mathrm{tha}^{-1}$. 
In the literature, fruits yield of Japanese cucumber in greenhouse above $100 \mathrm{t} \mathrm{ha}^{-1}$ have been reported (Fontes \& Puiatti, 2005; Filgueira, 2008), which is higher than that obtained in the present study. This fact is related with the high incidence of Leandria momordicae in the Japanese cucumber plants during the experiment, especially during the period of fruit production (due to the low control efficiency of the pesticides used). This disease which contributed to the reduction of the cultural cycle of Japanese cucumber and its fruits yield, because fruits yield of cucumber has been proportional to the duration of cultural cycle (Fontes \& Puiatti, 2005).

Currently, sustainability is the great challenge for agricultural production, and optimization of the factors of production is of fundamental importance to achieve sustainable production, especially in regard to the use of fertilizers. Thus, it is important to determine the maximum economic efficiency $\mathrm{N}$ doses for the two $\mathrm{N}$ sources used in the present study.

The maximum economic efficiency $\mathrm{N}$ dose for the fruits yield of Japanese cucumber using ammonium sulfate as $\mathrm{N}$ source was $398 \mathrm{~kg} \mathrm{ha}^{-1}$, with fruits yield of $76.4 \mathrm{t} \mathrm{ha}^{-1}$ (increase of $136 \%$ in relation to the lowest $\mathrm{N}$ dose used). Using ammonium nitrate as $\mathrm{N}$ source, the maximum economic efficiency $\mathrm{N}$ dose for the fruits yield of Japanese cucumber was $386 \mathrm{~kg} \mathrm{ha}^{-1}$, with fruits yield of $76.3 \mathrm{~kg} \mathrm{ha}^{-1}$ (increase of $135 \%$ in relation to the lowest $\mathrm{N}$ dose used). The maximum economic efficiency $\mathrm{N}$ doses for the two $\mathrm{N}$ sources used were near to that responsible for the maximum fruits yield of Japanese cucumber (98 and $95 \%$, using as source ammonium sulfate and ammonium nitrate, respectively), indicating that the Japanese cucumber presents a high economic response to $\mathrm{N}$ fertilization.

\subsection{Nitrate $\left(\mathrm{NO}_{3}^{-}\right)$Accumulation in Fruits}

$\mathrm{NO}_{3}{ }^{-}$content on Japanese cucumber fruits as a function of the $\mathrm{N}$ sources and doses used was not verified, suggesting that this crop (or cultivar) presents low tendency to $\mathrm{NO}_{3}{ }^{-}$accumulation in fruits, even in the presence of high $\mathrm{N}$ supply. Although it is related in the literature that the increasing in $\mathrm{N}$ supply is a determinant factor to $\mathrm{NO}_{3}^{-}$accumulation in plants (Pôrto et al., 2008, 2012a, 2012b, 2014b), other factors also influence this accumulation. Ohse et al. (2012) reported that the $\mathrm{NO}_{3}{ }^{-}$accumulation capacity in plants is of genetic character, being verified difference in the $\mathrm{NO}_{3}{ }^{-}$accumulation between the different plant species, between cultivars of the same species and even between different plant organs (Santamaria, 2006). Other studies shown that leafy vegetables have a high tendency to $\mathrm{NO}_{3}{ }^{-}$accumulation (Santamaria, 2006; Takahashi et al., 2007; Pôrto et al., 2008, 2012a) while flower and fruit vegetables generally show lower $\mathrm{NO}_{3}{ }^{-}$accumulation (Silva et al., 2017).

The results of this study are in agreement with those obtained by Silva et al. (2017), which also observed a low $\mathrm{NO}_{3}{ }^{-}$accumulation in cucumber fruits $\left(0.193 \mathrm{mg} \mathrm{kg}^{-1}\right.$ of fresh mass) submitted to different $\mathrm{N}$ fertilizer sources (ammonium sulfate (100\% ammonium), ammonium nitrate (50\% ammonium and $50 \%$ nitrate), sodium nitrate $(100 \%$ nitrate) and urea $(100 \%$ amide)). The results of this study are also in agreement with the one observed for other cucurbits, such as zucchini and of hybrid winter squash ('Tetsukabuto' type), where it has also been verified a low tendency to $\mathrm{NO}_{3}{ }^{-}$accumulation in fruits, even submitted to high $\mathrm{N}$ supply with the use of different $\mathrm{N}$ sources (Porto et al., 2012b, 2014b).

The $\mathrm{NO}_{3}{ }^{-}$accumulation in plants occurs when there is an imbalance between uptake and assimilation of this ion by plants (Pôrto et al., 2012a, 2012b, 2014b). After uptake by the roots, $\mathrm{NO}_{3}{ }^{-}$must be reduced to $\mathrm{NH}_{4}{ }^{+}$to be assimilated by plants and form the various nitrogen compounds (amino acids, proteins and others). This reduction $\mathrm{NO}_{3}^{-}$in $\mathrm{NH}_{4}{ }^{+}$occurs in two steps, catalyzed by the enzymes Nitrate Reductase and Nitrite Reductase (Braun et al., 2013). The reduction of $\mathrm{NO}_{3}^{-}$in $\mathrm{NH}_{4}^{+}$is regulated by plant and may occur completely in the roots or completely in the leaves or both. The site and/or reduction ratio is dependent on plant specie. However, $\mathrm{NO}_{3}{ }^{-}$ is very tolerated by plants, and when uptaked in an amount exceeding the reduction capacity, this can be accumulated (stored) in the vacuole without causing plant toxicity (Silva et al., 2017). $\mathrm{NH}_{4}{ }^{+}$, resulting from the reduction of $\mathrm{NO}_{3}{ }^{-}$or when absorbed by the plant in this form, is incorporated into amino acids by the action of enzymes GS-GOGAT (Glutamine Synthase and Glutamine Oxoglutarate Amide Transferase, respectively). What makes a determined plant specie to uptake high or low amount of $\mathrm{N}$ in $\mathrm{NH}_{4}{ }^{+}$form is its assimilatory capacity (ability to incorporate $\mathrm{NH}_{4}{ }^{+}$into amino acids). If this assimilatory capacity is exceeded, $\mathrm{NH}_{4}{ }^{+}$promote the decoupling of the electron transport chain from the membranes of chloroplast (in leaves) and/or mitochondria, manifested by toxicity (Silva et al., 2017).

Low $\mathrm{NO}_{3}{ }^{-}$accumulation observed in cucumber fruits led to Silva et al. (2017) infer that the cucumber has great regulatory capacity in relation to the amount of $\mathrm{N}$ uptaken in the ammoniacal form or in the reduction of $\mathrm{NO}_{3}{ }^{-}$to $\mathrm{NH}_{4}{ }^{+}$when supplied in nitric form. Theses authors also affirmed that if nitrate is to be accumulated in cucumber plants, this accumulation occurs in other tissues, except in the fruits. 
The United Nations Food and Agriculture Organization (FAO) and the World Health Organization (WHO) established the acceptable daily intake limit of $\mathrm{NO}_{3}{ }^{-}$by humans of $3.7 \mathrm{mg} \mathrm{kg}^{-1}$ of body mass (WHO, 1995). As there was no $\mathrm{NO}_{3}{ }^{-}$content in the Japanese cucumber fruits using $\mathrm{N}$ sources and doses in greenhouse, this crop (or cultivar) presents low risk to human health.

\section{Conclusions}

The $\mathrm{N}$ sources used (ammonium sulfate and ammonium nitrate) showed similar agronomic efficiency for the Japanese cucumber cultivation in greenhouse, being ammonium sulphate more indicated because it presents better cost-benefit.

The maximum economic efficiency $\mathrm{N}$ doses for fruits yield of Japanese cucumber in greenhouse were $398 \mathrm{~kg}$ $\mathrm{ha}^{-1}$ and $386 \mathrm{~kg} \mathrm{ha}^{-1}$, resulting in fruits yield of $76.38 \mathrm{t} \mathrm{ha}^{-1}$ and $76.29 \mathrm{t} \mathrm{ha}^{-1}$ for ammonium sulfate and ammonium nitrate, respectively.

Japanese cucumber ('Taisho' hybrid) presents low tendency to $\mathrm{NO}_{3}{ }^{-}$accumulation in fruits, even submitted to high $\mathrm{N}$ supply with the use of different $\mathrm{N}$ sources, presents low risk to human health.

\section{Acknowledgements}

To CNPq for granting the scholarship of DS to the first author and research productivity to the second, third and fourth authors.

To PRPI/IFAL for granting the research productivity scholarship (PAPPE/IFAL) to the first and fifth authors.

For FAPEMIG, for the support to carry out this study.

\section{References}

Abbasi, M. K., Tahir, M. M., \& Rahim, N. (2013). Effect of N fertilizer source and timing on yield and N use efficiency of rainfed maize (Zea mays L.) in Kashmir-Pakistan. Geoderma, 195-196, 87-93. https://doi.org/ 10.1016/j.geoderma.2012.11.013

Antunes, G., Ferreira, A. P. S., Puiatti, M., Cecon, P. R., \& Silva, G. C. C. (2014). Produtividade e qualidade de frutos de pepino africano em resposta à adubação nitrogenada. Revista Ceres, 61, 141-146. https://doi.org/ 10.1590/S0034-737X2014000100019

Braun, H., Coelho, F. S., Silva, M. C. C., Fontes, P. C. R., Cecon, P. R., \& Busato, C. (2013). Absorção, metabolismo e diagnóstico do estado de nitrogênio em plantas de batata. Revista de Ciências Agrárias, 56, 185-195. https://doi.org/10.4322/rca.2013.028

Cardoso, A. I. I., \& Silva, N. (2003). Avaliação de híbridos de pepino tipo japonês sob ambiente protegido em duas épocas de cultivo. Horticultura Brasileira, 21, 170-175. https://doi.org/10.1590/S0102-053620030 00200010

Cataldo, D. A., Haroon, M., Schrader, L. E., \& Youngs, V. L. (1975). Rapid colorimetric determination of nitrate in plant tissue by nitration of salicylic acid. Communication Soil Science and Plant Analysis, 6, 71-80. https://doi.org/10.1080/00103627509366547

CEASA-MG (Central de Abastecimento do Estado de Minas Gerais). (2011). Preços e ofertas de produtos. Retrieved from http://www.ceasaminas.com.br

CONAB (Companhia Nacional do Abastecimento). (2011). Preço dos insumos agropecuários. Retrieved from http://www.conab.gov.br

EMBRAPA (Empresa Brasileira de Pesquisa Agropecuária). (1997). Manual de métodos de análise de solo (2nd ed.). Rio de Janeiro: EMBRAPA-CNPS.

EMBRAPA (Empresa Brasileira de Pesquisa Agropecuária). (2013). Sistema Brasileiro de Classificação de Solos (3rd ed.). Rio de Janeiro: EMBRAPA-CNPS.

Filgueira, F. A. R. (2008). Novo manual de olericultura (3rd ed.). Viçosa-MG: UFV.

Fontes, P. C. R., \& Puiatti, M. (2005). Cultura do pepino. In P. C. R. Fontes (Ed.), Olericultura: Teoria e prática (pp. 439-455). Viçosa, MG: UFV.

Ohse, S., Carvalho, S. M., Rezende, B. L. A., Oliveira, J. B., Manfron, P. A., \& Dourado Neto, D. (2012). Produção e composição química de hortaliças folhosas em hidroponia. Bioscience Journal, 28, 155-163. Retrieved from http://www.seer.ufu.br/index.php/biosciencejournal/article/view/8151/8471 
Oliveira, A. P., Oliveira, A. N. P., Alves, A. U., Alves, E. U., Silva, D. F., Santo, S. R. R., \& Leonardo, F. A. P. (2008). Rendimento de maxixeiro adubado com doses de nitrogênio. Horticultura Brasileira, 26, 533-536. https://doi.org/10.1590/S0102-05362008000400022

Pôrto, M. L. A., Puiatti, M., Fontes, P. C. R., Cecon, P. R., \& Alves, J. C. (2014a). Índice SPAD para o diagnóstico do estado de nitrogênio na cultura do pepino japonês em ambiente protegido. Horticultura Brasileira, 32, 292-296. https://doi.org/10.1590/S0102-05362014000300009

Pôrto, M. L. A., Puiatti, M., Fontes, P. C. R., Cecon, P. R., \& Alves, J. C. (2014b). Produtividade e acúmulo de nitrato nos frutos da abóbora "Tetsukabuto" em função da adubação nitrogenada. Horticultura Brasileira, 32, 280-285. https://doi.org/10.1590/S0102-05362014000300007

Pôrto, M. L. A., Puiatti, M., Fontes, P. C. R., Cecon, P. R., Alves, J. C., \& Arruda, J. A. (2012b). Produtividade e acúmulo de nitrato nos frutos de abobrinha em função da adubação nitrogenada. Bragantia, 71, 190-195. https://doi.org/10.1590/S0006-87052012005000020

Pôrto, M. L., Alves, J. C., Souza, A. P., Araujo, R. C., \& Arruda, J. A. (2008). Nitrate production and accumulation in lettuce as affected by mineral Nitrogen supply and organic fertilization. Horticultura Brasileira, 26, 227-230. https://doi.org/10.1590/S0102-05362008000200019

Pôrto, M. L.A., Alves, J. C., Souza, A. P., Araújo, R. C., Arruda, J. A., \& Tompson Júnior, U. A. (2012a). Doses de nitrogênio no acúmulo de nitrato e na produção da alface em hidroponia. Horticultura Brasileira, 30, 539-543. https://doi.org/10.1590/S0102-05362012000300030

Queiroga, R. C. F., Puiatti, M., Fontes, P. C. R., Cecon, P. R., \& Finger, F. L. (2007). Influência de doses de nitrogênio na produtividade e qualidade do melão Cantalupensis sob ambiente protegido. Horticultura Brasileira, 25, 550-556. https://doi.org/10.1590/S0102-05362007000400011

Raij, B. V. (2011). Fertilidade do solo e manejo de nutrientes. Piracicaba: IPNI.

Ribeiro, A. C., Guimarães, H., \& Alvarez V., V. H. (1999). Recomendações para uso de corretivos e fertilizantes em Minas Gerais— $5^{a}$ Aproximação. Viçosa, MG: CFSEMG.

SAEG (Sistema para Análises Estatísticas). (2007). Sistema para Análises Estatísticas (V. 9.1). Viçosa: Fundação Arthur Bernardes.

Santamaria, P. (2006). Nitrate in vegetables: toxicity, content, intake and EC regulation. Journal of the Science of Food and Agriculture, 86, 10-17. https://doi.org/10.1002/jsfa.2351

Santi, A., Scaramuzza, W. L. M. P., Soares, D. M. J., Scaramuzza, J. F., Dallacort, R., Krause, W., \& Tieppo, R. C. (2013). Desempenho e orientação do crescimento do pepino japonês em ambiente protegido. Horticultura Brasileira, 31, 649-653. https://doi.org/10.1590/S0102-05362013000400023

Santos, M. E. R., Fonseca, D. M., Gomes, V. M., Gomide, C. A. M., Nascimento Júnior, D., \& Queiroz, D. S. (2011). Capim-braquiária sob lotação contínua e com altura única ou variável durante as estações do ano: morfogênese e dinâmica de tecidos. Revista Brasileira de Zootecnia, 40, 2323-2331. https://doi.org/ $10.1590 / \mathrm{S} 1516-35982011001100007$

Silva, G. C. C., Puiatti, M., Cecon, P. R., \& Freitas, A. R. J. (2017). Crescimento, produtividade e nitrato em frutos de pepino submetidos a fontes de adubos nitrogenados. Revista Brasileira de Ciências Agrárias, 12, 179-184. https://doi.org/10.5039/agraria.v12i2a5441

Silva, V. F. A., Melo, N. C., Galvão, J. R., Silva, D. R., Pereira, W. V. S., \& Rodrigues, F. H. S. (2015). Produção de melancia e teores de sólidos solúveis totais em resposta a adubação nitrogenada e potássica. Revista Brasileira de Agricultura Irrigada, 9, 136-144. https://doi.org/10.7127/rbai.v9n300299

WHO (World Health Organization). (1995). Evaluation of certain food additives and contaminants (WHO Technical Report Series, 859). Forty-fourth report of the Joint FAO/WHO Expert Committee on Food Additives. Geneva: FAO/WHO.

\section{Copyrights}

Copyright for this article is retained by the author (s), with first publication rights granted to the journal.

This is an open-access article distributed under the terms and conditions of the Creative Commons Attribution license (http://creativecommons.org/licenses/by/4.0/). 